\title{
PERSONAL VALUES AND INTRAGROUP RELATIONSHIP: THE CASE OF THE POLICE TACTICAL GROUPS IN BRASÍLIA
}

\author{
FAGNER O. DIAS \\ (iD) https://orcid.org/0000-0001-6529-5485 \\ EDGAR REYES JUNIOR ${ }^{1}$ \\ (iD) https://orcid.org/0000-0001-7403-5909 \\ CAROLINE C. B. COSTA \\ (iD) https://orcid.org/0000-0003-3251-0059 \\ ANDRÉIA E. S. BARROS ${ }^{1}$ \\ (iD) https://orcid.org/0000-0002-7409-0550
}

To cite this paper: Dias, F. O., Reyes, E., Junior, Costa, C. C. B., \& Barros, A. E. S. (2021). Personal values and intragroup relationship: The case of the police tactical groups in Brasília. Revista de Administração Mackenzie, 22 (5), 1-28. doi:10.1590/1678-6971/eRAMG210010

Submission: Jan. 23, 2020. Acceptance: Nov. 19, 2020.

${ }^{1}$ University of Brasília (UnB), Brasília, DF, Brazil.

\footnotetext{
(cc) $\mathbf{B Y}$

This paper may be copied, distributed, displayed, transmitted or adapted for any purpose, even commercially, if provided, in a clear and explicit way, the name of the journal, the edition, the year and the pages on which the paper was originally published, but not suggesting that RAM endorses paper reuse. This licensing term should be made explicit in cases of reuse or distribution to third parties.

Este artigo pode ser copiado, distribuído, exibido, transmitido ou adaptado para qualquer fim, mesmo que comercial, desde que citados, de forma clara e explícita, o nome da revista, a edição, o ano e as páginas nas quais o artigo foi publicado originalmente, mas sem sugerir que a RAM endosse a reutilização do artigo. Esse termo de licenciamento deve ser explicitado para os casos de reutilização ou distribuição para terceiros.
} 


\section{ABSTRACT}

Objectives: This article aims to describe how the personal values of members of specialized workgroups impact their intra-group relationships based on professional and personal trust.

Originality/value: The contributions of this study are threefold: 1 . the consolidation that the analysis of trust in work groups has different results in the instrumental (professional or reputation trust) and the experimental (personal or friendship trust) relationship when verifying difference in the predominance of personal values for each type relationship; 2. the use of the functionalist theory of human values and to the use of social network analysis techniques and in conjunction with classical quantitative techniques such as ANOVA and multiple regression; 3. the verification of personal values that contributes to the organization and how trust relationships are structured in the group.

Design/methodology/approach: The present study is characterized as descriptive field research with a quantitative approach. A survey was conducted with 171 participants from the two tactical groups of the Brasília police, using the Basic Values Questionnaire (BVQ) questionnaire of functionalist values and a questionnaire with eight questions about the instrumental and expressive relationship. Confirmatory factor analysis was used to evidence the validity of the instrument, analysis of social networks (ASN) for trust relationships and ANOVA, and multiple regression for relationships between values and relationships.

Findings: The tactical groups presented characteristics of more pragmatic personal values and with less appreciation of individualism, denoting characteristics of appreciation of execution and intragroup collectivism. The normative and supra-personal values were negatively related, respectively, to friendship and professional relationships, while the achievement value was positively related to both trust relationships.

\section{KEYWORDS}

Personal values. Confidence. Social networks. Friendship. Professional reputation. 


\section{INTRODUCTION}

Whether in life in society or in the work environment, interpersonal relationships are fundamental for personal and task development, after all, human beings share beliefs, values and learn and develop through relationships. Within the professional environment, new interpersonal relationships and the formation of workgroups are stimulated. This can impact the organization's performance, given that new professional relationships can be integrative, as in cases of group cohesion and integration or disruptive due to conflicts and unhealthy competitiveness. Thus, for the performance to be satisfactory and for the team to be effective, it is not enough that the group members are highly qualified. It is necessary for the team to be able to work together to be successful in achieving its goal.

However, social relationships in a group are unevenly distributed - each pair of relationships is different from the others. For this reason, these relationships are called dyadic, in that each member has a different relationship with another member of the group, forming relationship pairs. From these relationships comes the sharing of personal values that form the trust between the members of an organization (Reed, 2001). Relationships of friendship arise from this trust, which is important because they can change the values and behaviors of individuals, changing their way of being and even their character (Bernstein, 2007). Personal values are conceptions of an individual whose role is more than an action advisor, it is a representative of the principles, criteria, or goals that guide the lives of human beings (Schwartz, 1992).

In social network relationships, trust is an essential element for the effectiveness of relationships between the actors within the network. Relationships based on trust have been evidenced in several organizational theories and economic sociology studies (De Jong, Dirks, \& Gillespie, 2016; Martins, Faria, Prearo, \& Arruda, 2017). Reed (2001) defends trust as a representation of a coordinating mechanism based on the sharing of moral values and collective norms to support cooperation and collaboration in uncertain environments.

Thus, considering that personal values embody principles that guide the lives of human beings, also guiding their trust relations, which can directly impact performance, the following question arises:

- How do personal values influence relationships in police tactical groups? 
To answer the study question, the population of analysis chosen was that of the tactical groups of the Military Police in Brasília, the capital of Brazil. These groups have the specific mission of coping with high-risk police events involving firearms. The choice is due to the fact that these groups have the specific characteristic of being constantly at a high alert level and under pressure from the risk of death, which presupposes different relational levels and sharing of values, and that an informal social interaction and trust structure have a considerable influence on the effectiveness of the network.

\section{THEORETICAL GROUNDS}

\subsection{Interpersonal relations and trust}

Initial studies on interpersonal relationships have established that group productivity and efficiency are dependent not only on the individual competence of its members but, above all, on mutual help within their interpersonal relationships (Lewin, 1947). In the last century, the term "social networks" was used freely to refer to the various sets of relationships between participants in existing social systems of different scales and dimensions, from personal relationships to institutional relationships (Lima \& Pereira, 2017).

Work environment social networks analysis has presented antagonistic results. It has been proposed that the relational constructs be analyzed in two types of relationships: instrumental (focused on the execution of the task) and expressive (focused on personal relationships), supplying a rare distinction between friendly relations and friendship, because when analyzing the structure, one can observe the types of resources and information flow which, in a broad way, can explain the workgroup processes that influence its performance (Henttonen, Janhonen, \& Johanson, 2013). The division of the analysis of relational constructs such as trust has been reinforced in other studies (Crawford \& Lepine, 2013) that separate the analysis into instrumental (relationship by reputation) and expressive (relationship by friendship).

In social networks, interpersonal relationships, their links, and informal relationships are valued over formal hierarchical structures (Marteleto, 2001). Interpersonal relationships are inherent in a social environment, professional or not, where relationships and constant flow of information occur. To understand information flows and relationships in social networks, as 
well as their influence, it is essential to investigate the connections and interactions of the actors in the network (Vergueiro \& Sugahara, 2010).

It is possible to map the various transactions and relational dimensions when defining criteria such as friendship, trust, information, and norms, among others (Nahapiet \& Ghoshal, 1998). Trusting essentially refers to the extent to which a person is willing to act based on the words, actions, and decisions of another (McAllister, 1995). Thus, interpersonal trust can be defined as an individual's willingness to be vulnerable to the other part of the relationship based on positive expectations of the other's actions (Rousseau, Sitkin, Burt, \& Camerer, 1998). It should be noted that trust on a dyadic level may not always converge to mutuality. Hence it is important to always consider both sides of the relationship (Korsgaard, Brower, \& Lester, 2015). It cannot be assumed that the level of trust will be the same for each person. Thus, the importance of the social network approach used in this study is highlighted.

Friendships are important because they can change people's values and behaviors, changing an individual's way of being (Bernstein, 2007). This trust is an essential element for the effectiveness of interpersonal relationships through the reduction of relational uncertainties. Trust can be seen as a "cousin" of power and influence in a network that, although based on the past, guides the future of actions and relationships (Thorelli, 1986). The establishment of bonds of trust does not occur only through the direct relationship between the parties. It can also be established indirectly through the perception of third parties. Therefore, whether on an individual or collective perception, a person can trust because his friend or his group trusts and shares the same values. The mechanism by which trust is established by others can also be called interpersonal reputation (Ryan, 2004).

Due to the interdependence inherent to group work, trust between team members is necessary for the process and effective performance of the group, as it affects the ability and willingness to work together towards a common goal (Mayfield, Tombaugh, \& Lee, 2016). The extent of the effect of intragroup trust on performance has an estimated magnitude that is greater than the average estimate of other constructions at the team level, i.e., by about $60 \%$ greater than the average in the organizational field (De Jong et al., 2016), reaffirming the importance of confidence related to teamlevel performance.

In organizational relationships, trustworthy behavior contributes to building trust among members and can be categorized into the following: behavioral consistency, behavioral integrity, sharing and delegation of control, 
communication, and show of concern (Whitener, Brodt, Korsgaard, \& Werner, 1998). Studies on behavior, one of the main topics in social psychology, commonly consist of two predictors: values and attitudes (Milfont, Duckitt, \& Wagner, 2010). The structural relationship between value-attitude-behavior began with research on food purchases (Homer \& Kahle, 1988) and continues to several other topics such as the use of alcoholic beverages (Medeiros, Pimentel, Monteiro, Gouveia, \& Medeiros, 2015) and transformational leadership ((Castillo, Adell, \& Alvarez, 2018). Thus, values are on the basis of attitudes and behaviors.

Interpersonal relationships played an explanatory role in studies involving organizational well-being associated with the congruence of personal values. The study by Sortheix and Lönnqvist (2015), conducted in the university environment, demonstrated that greater similarity of personal values showed a beneficial effect on the well-being of the organizational environment, corroborating studies on the level of person-environment in which the compatibility between individual and work environment is favorable when their characteristics are well combined (Maslach \& Leiter, 2008). To understand the bonds of trust, it is believed that there is a relationship between these bonds and the personal values of each individual, as trust represents a coordination mechanism based on the sharing of values (Reed, 2001). In addition, personal values are the representatives of the principles, criteria, or goals that guide human beings (Schwartz, 1992). Thus understanding them may be a predictor of the bonds of trust in the organization.

\subsection{Personal values}

Understanding personal values means identifying human beings in their essence. Human nature and behaviors depend on the valuation criteria that each person observes. The study of human values has matured and accumulated knowledge since the study of the cultural transformation of the Polish immigrant in America (Thomas \& Znaniecki, 1919), to the values orientation in the theory of action (Kluckhohn, 1951), and the study of motivation and personality (Maslow, 1954), to the nature of human values (Rokeach, 1973), and the present time, marked by cross-cultural validity test of models, dominated by the theory of basic and individual values (Schwartz, 1992, 2006, 2012) and more parsimonious versions like the functionalist theory of human values (Gouveia, 2003).

Personal value can be defined as a desirable principle: it is "a conception, explicit or implicit, distinctive of an individual or characteristic of a 
group, of the desirable which influences the selection from available modes, means and ends of actions" (Kluckhohn, 1951, p. 473). This definition was considered a fertile ground for other researchers (Gouveia, 2003; Rokeach, 1973; Schwartz, 1992; Schwartz et al., 2012). Rokeach's (1973) studies are considered to be the essence of value models and a mandatory reference for any researcher who wants to study human values, such as those that would come decades later, like Schwartz and Gouveia. Rokeach (1973) believes that a person's total values can be represented in a relatively small number and that all people have identical values organized in a systemic way, varying only in intensity and separates the values in terminals (characterizing final states of existence) and instrumental (modes of conduct, being competent and moral).

Understood as criteria for evaluating actions, other people, and events, the refined theory of basic and individual values model (Schwartz et al., 2012) is the main reference in the field of human values today. Human values can be defined as principles, criteria, or goals that transcend specific actions and situations, ordered by their relative importance to others and that guide the lives of individuals. Unlike the simple study of a list of values, the model started to study a set of motivational goals in decision making (Schwartz, 1992). This theory proposed a unifying model of human values as a dynamic structure among motivational categories of values in which the individual prioritizes compatible values and treats incompatible ones with low priority in a non-random way, therefore allowing the ability to predict attitudes and behaviors. In the refined version of the theory (Schwartz et al., 2012), values are defined and ordered within a format that is based on compatible and conflicting emotions, protection of the ego against growth, and individual focus vis a vis social focus within 19 basic human values. In Brazil, the model also obtained validation indexes (Torres, Schwartz, \& Nascimento, 2016).

\subsection{Functionalist theory of human values}

Another model that emerged and was validated in Brazil is the functionalist theory of human values (Gouveia, 2003). It began to be developed in the late 1990s and has evolved since then (Gouveia, 2003; Gouveia, Milfont, \& Guerra, 2014a; Medeiros et al., 2012). Although less known than the theory of basic and individual values (Schwartz, 1992), by the year 2011, this model has been used in studies conducted with more than 50,000 people from twelve different countries, including Brazil (Medeiros, 2011). The functionalist theory was chosen as an analysis model for the present study 
because, in addition to being consistent, it is also more parsimonious, containing only six main values and with a questionnaire that can be applied for approximately three minutes ((Gouveia, Milfont, \& Guerra, 2014b) while the application of the refined Basic Values Questionnaire (BVQ) takes ten minutes (Schwartz, 2014).

In the functionalist theory, values are seen as guiding principles that are available to anyone, differing only in magnitude, which is influenced by the type of an individual's socialization and socio-cultural context (Gouveia, 2003). In theory, two consensual functions in the literature are proposed: 1. orientation type, which guides men's actions (Rokeach, 1973; Schwartz, 1992; Schwartz et al., 2012); and 2. motivation type, which express human needs (Maslow, 1954). Thus, the functions of values are defined as aspects of a psychological nature that guide behaviors and represent human cognitive needs (Gouveia, Milfont, Fischer, \& Coelho, 2009).

The first function of guiding human behavior, called orientation type, consists of three possibilities of orientation: social, central, and personal. The personal and social value dimensions, already defined in the terminal values (Rokeach, 1973), have been seen as important in human orientation (Hofstede, 1980). In these, people guided by personal values have an intrapersonal focus, more egocentric, while those guided by social values have an interpersonal focus centered on society. The central dimension, on the other hand, refers to values that are positioned between the social and the personal. This third group, or central, is necessary because it is the reference of the other two and serves as a structuring base and is considered for general life purposes, such as survival (Gouveia et al., 2014a).

The second function of expressing human needs, called the motivator type, is composed of two classifications of cognitive needs: materialistic (pragmatic) and humanitarian (idealistic). Materialistic values express basic, biological, and social needs, which highlight specific objectives of immediate interest, that is, observance of normative rules, giving importance to the conditions that can ensure one's own existence. Humanitarian values express universal goals based on more abstract ideas and principles, valuing interpersonal relationships as an end in themselves (Gouveia et al., 2009).

By combining the two functions, the six subfunctions are obtained, which are the basis of the functionalist theory of human values. Thus, the six sub-functions are: 1. normative (social-materialist); 2 . interactive (socialidealistic); 3. existence (central-materialist); 4. supra-personal (central-idealistic); 5. promotion (personal-materialistic); and 6. excitement (personal-idealistic). It can be represented by Figure 2.3.1. 


\section{(Figure 2.3.1) \\ BASIC VALUES DIMENSIONS AND SUB-FUNCTIONS}

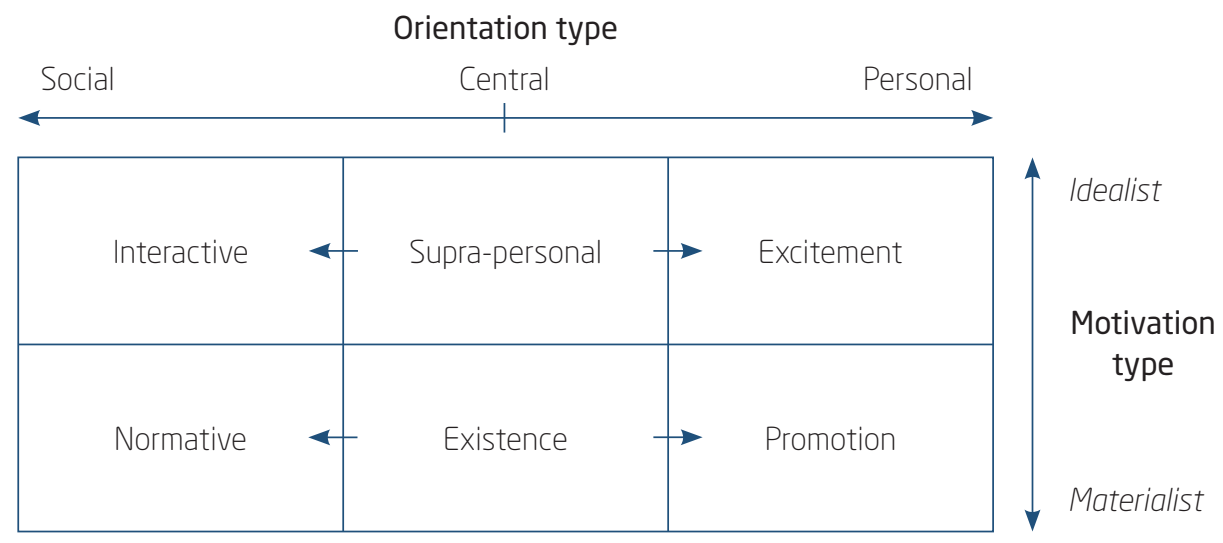

Source: Adapted from Gouveia et al. (2009).

The six sub-functions and the values selected to represent them will be described below. It is important to note, however, that it is possible for other researchers to consider a different set of values according to their culture or environmental context (Gouveia et al., 2009).

1. Normative: This is a social-materialist type, reflecting the importance of maintaining social norms and cultures. The basic values in this subfunction are obedience, religiosity, and tradition (Braithwaite \& Scott, 1991; Schwartz, 1992). They usually guide older people following conventional norms and opposing unconventional behavior.

2. Interactive: It is a social-idealistic type, reflecting the importance of affective experience among individuals. It represents the needs for belonging, love, and affiliation, emphasizing more affective and abstract attributes. Its basic values are affection, coexistence, and social support (Rokeach, 1973; Schwartz, 1992). They usually guide younger people and are oriented towards stable intimate relationships, especially in the family constitution.

3. Existence: It is a central-materialist type, reflecting the most important subfunction of the materialist motivator since its main purpose is to ensure the basic conditions for the biological and psychological survival of the individual. It usually guides people in a context of economic scarcity or those who have been socialized in environments with such characteristics. Its basic values are health, personal stability, and survival (Braithwaite \& Law, 1985; Levy, 1990). 
4. Supra-personal: It is a central-idealistic type, reflecting the most important subfunction of the idealistic motivator since its main purpose is to supply the superior need for self-realization, as well as aesthetics and cognition. It indicates the importance of abstract ideas, with less emphasis on concrete and material things. This usually guides people who think more broadly and generally. Its basic values are beauty, knowledge, and maturity (Braithwaite \& Law, 1985; Levy, 1990; Rokeach, 1973; Schwartz, 1992).

5. Promotion: it is a personal-materialistic type, reflecting the needs of selfesteem through material realization. It represents immediacy with a focus on material and personal fulfillment. It usually guides people who give importance to a hierarchy based on personal competence, often being young adults in their productive phase or individuals educated in disciplinary and formal contexts who appreciate an organized and structured society. Its basic values are power, success (Braithwaite \& Scott, 1991), and prestige (Schwartz, 1992).

6. Excitement: it has a personal-idealistic type, reflecting the physiological needs for satisfaction or the pleasure principle. The search for status, harmony and social security is less pragmatic, and values are focused on promoting changes and innovations in social organizations. It usually guides young people who tend not to conform to social rules. Its basic values are emotion (Schwartz, 1992), pleasure, and sexuality (Braithwaite \& Scott, 1991).

Thus, the composition of the functionalist values (Gouveia et al., 2009; Gouveia et al., 2014a) has the combination of two functional dimensions as its main structure. One corresponding to the type of orientation (social, central, or personal) and the other one to the type of motivation (materialistic or idealistic), which, when combined in a 2 × 3 matrix, yields six specific subfunctions, which are the theoretical markers of the theory.

Although all the valuative subfunctions are present in the individual, obtaining the predominant values of the members, combined with team performance, may indicate a correlation of values considered desirable in the selection of these members. In a top management survey, it was found that the value of opening leaders to change in cases preceding poorly structured problems was positively related to the performance of team members (Riviera, Domenico, \& Sauaia, 2014). On the other hand, in a survey of leaders from small groups, altruistic values were positively related to the team effectiveness while conservative values were negatively related to it (Van Dun \& Wilderom, 2016). 
Although the two surveys analyzed data from different perspectives, one with top management groups and the other only with the leaders of small groups, similarities were observed in the values correlated to the effectiveness or performance of the working groups. For the authors, the differences in conservative intragroup values or their prevalence in leadership are negatively related to performance. Both surveys conducted analyses based on the refined theory of basic and individual values (Schwartz et al., 2012), currently a globally dominant theory. However, an evaluation from the perspective of another scale of values, such as the functionalist theory, is important.

It is, therefore, necessary to understand the personal values in the workgroups and how they are characterized and influence intra-group relationships that have a direct impact on performance.

\section{METHODOLOGICAL PROCEDURE}

The present study is characterized as a descriptive field research with a quantitative approach. For this analysis, a survey was conducted with military policemen from Brasília, who make up the battalions of motorized tactical groups of the Military Police of the Federal District (Polícia Militar do Distrito Federal - PMDF). Such characteristics fit into the tactical groups of Motorized Tactical Ostensive Rounds (Rondas Ostensivas Táticas Motorizadas Rotam) and Mobile Tactical Patrolling (Patrulhamento Tático Móvel - Patamo). As it addresses the totality of the military police officers working in the core activity, this study is considered as a census because it addresses the totality of the universe in question (Marconi \& Lakatos, 2003).

The data collection instrument (DCI) used was composed of three blocks: 1. socioeconomic data; 2. a two-part relational questionnaire adapted from Burt (1992) with each part composed of four structured questions in which the respondent must say the names of those he/she maintains the type of relationship described, be it in the service environment for performing the task or outside professional relationships, in personal relationships, this is to separate instrumental and expressive networks; and 3. BVQ already tested and with validation indexes in several countries, including Brazil, prepared by Gouveia (2003). The BVQ includes closed questions answered within the continuous interval scale from 1 to 7 , with 1 being the lowest intensity (totally unimportant) and 7 for the highest intensity (extremely important). 
The survey-type DCI was applied in person using a printed questionnaire. The police officers responded to the survey form in a classroom in their own work environment. To validate the relational aspect of the questionnaire, a pre-test was applied, with 20 policemen from the Operational Tactical Group (Grupo Tático Operacional - GTOP) from an administrative region of Brasília. As a result, it was necessary to change the order of relational questions since respondents were more susceptible to answering instrumental questions ahead of expressive ones. To validate the data collection instrument used to measure personal values, a confirmatory factor analysis (CFA) was performed. In this study, as suggested by Hair, Black, Babin, Anderson, and Tatham (2009), the CFA was used to validate the measurement model to determine whether the relationships between the 18 valuative markers and the six functionalist values of Gouveia (2003) are supported by the data, according to the research objectives.

As for the relationships between the actors, the most important measures used are those of centrality, which correspond to the number of relationships that arise between an actor and other actors. In the analysis of social networks (ASN), concepts such as centrality are related to research on power and network prestige. According to Borgatti, Everett, and Johnson (2018) and Wasserman and Faust (1994), these measures identify the "most important" actors in the social network. While centrality, in general, assesses an actor's privileged position in undirected relationships, prestige is the analysis of centrality in targeted relationships. Therefore, the notion of prestige is quantified by the actors' choices, and it is not necessarily reciprocal, for which the analysis of a directional graph is necessary (Wasserman \& Faust, 1994).

When talking about centrality for targeted and non-valued networks, such as trust, Borgatti et al. (2018) states that the most appropriate measures are:

- Degree centrality: It is measured from the number of relational ties of the actor. It allows the visualization of the actors who assume central roles within the context of the network. It can be divided into the degree of entry (number of ties the actor receives) and degree of exit (number of ties the actor establishes). Wasserman and Faust (1994) indicate that the degree of exit measures the expansiveness of the actor in the network, while the degree of entry measures the power, prestige, reputation, or receptivity of the actor in the network.

- Beta centrality (Bonacich power): It considers attenuation or amplification factors resulting from indirect connections and the prestige generated 
by them, which alter the centrality. Thus, another way of measuring power in the network is to analyze the actors who have many relationships with actors with a low degree of centrality. These would have greater power, according to Bonacich (1987), since they connect to many who have few relational ties with other actors. Therefore, from this perspective, the actor with a greater power, in addition to having many relational ties, must have them with actors of less prestige in the network. Therefore, one can think of beta centrality as a measure of the total amount of potential influence that an actor can have over others through direct and indirect channels (Borgatti et al., 2018).

For analysis, groups were created according to the centrality of degree or beta. The division of the groups was conducted based on the average of the centrality value of the individuals, separated initially into two groups. Within the two groups, the average of the centralities was recalculated, and a new division was created, obtaining a total of four centrality groups: high centrality, medium-high centrality, medium-low centrality, and low centrality. The groupings formed in the metric variables in categorical variables were analyzed by varying the mean. Analysis of variance (ANOVA) was used to describe the differences in the model variables based on categorical variables. For cases in which the ANOVA test was significant $(\mathrm{p}<0.05)$ and there were more than two groups, the Tukey and Bonferroni post hoc test was also performed. With the significant results, bar graphs were created in the Excel software with the experimental error bar expressed by the standard error of ANOVA.

Finally, multiple regression was used to assess the relationship between the dependent variable and the independent variables. The initial exploratory method of regression was stepwise because it allows the researcher to examine the importance of each variable independent of the regression model. However, it is not a good indicator when more than one independent variable is only significant together in the regression (Hair et al., 2009). Subsequently, the Enter method, or insert, was used to assess whether there are variables that together have predictive power for the dependent variable. A system of structural equations was also used to analyze the proposed model according to the data found in the multiple regression.

In the period between June and August 2018, when the data collection was done, the battalions of Rotam and Patamo had, respectively, 122 and 76 police officers at the final activity, totaling 198 individuals. When the survey was conducted in the battalions, 107 respondents were obtained in Rotam ( $87.7 \%$ of the policemen in the related activity) and 64 in Patamo (84.2\% of 
the policemen in the related activity), a total population of 171 respondents out of the total 198. Twenty-seven police officers (15 from Rotam and 12 from Patamo) were not able to participate in the interview, as they were in one of the following situations: vacation, medical leave, assigned for instruction in another government agency, or paternity leave.

\section{DISCUSSION}

Personal values were collected based on the scale of Gouveia (2003), the BVQ, tested until 2011 on more than 50,000 people and in 12 different countries, including Brazil and regions (Medeiros, 2011). Each value is composed of three evaluative markers, totaling 18 , representing six values. Figure 4.1 describes the mean results $(m)$ of the responses as well as their standard deviation $(s d)$ as a result of the average responses of all respondents. A higher average was obtained for the religiosity value $(m=6.54, s d=0.92)$ and a lower average for the Beauty value $(m=4.21, s d=1.52)$. Checking the averages in descending order, together with their standard deviation, an initial observation shows that the five highest average value markers belong to the materialistic motivator type and the guiding type between central and social, that is, the five highest mean value markers belong to the normative and existence values. It was also verified that the highest average value markers were also those with the lowest standard deviation, denoting a lower response variance. Those with the lowest mean markers, below 5.00, also had a high standard deviation and, consequently, a greater variation in responses.

Still in Figure 4.1, it is possible to observe that the highest averages with the smallest variations in responses are in the normative and existence values, except for the marker tradition, which showed more constant values in the tactical groups. The supra-personal value showed a great response dissonance between the markers beauty and maturity, denoting that the tactical groups have homogeneity in the maturity marker, with a greater mean and low variation, and more heterogeneous in beauty, with a lesser mean and high variation. In the achievement value, the success marker stood out with the highest average and lowest deviation, denoting the importance of reaching the goals above power and prestige.

To analyze the six functional values, it was necessary to confirm the validation of that scale in the context of the research, and a CFA of the BVQ was also performed. For the CFA, the normality for the 18 items of the questionnaire was initially verified, in which all items were significant, $\mathrm{p}<0.001$, for the Kolmogorov-Smirnov (K-S) and Shapiro-Wilk (S-W) tests. The 
measure of normality is important because if the variation in relation to the normal distribution is sufficiently large, all statistical tests are invalid (Hair et al., 2009).

\section{(Figure 4.1)}

MEAN AND STANDARD DEVIATION OF VALUATION MARKERS

\begin{tabular}{lll}
\hline \multicolumn{1}{c}{ Interactive } & \multicolumn{1}{c}{ Supra-personal } & \multicolumn{1}{c}{ Excitement } \\
\hline Coexistence $(5.25 \pm 1.43)$ & Knowledge $(5.67 \pm 1.29)$ & Sexuality $(6.14 \pm 1.08)$ \\
Affection $(5.89 \pm 1.36)$ & Beauty $(4.14 \pm 1.52)$ & Pleasure $(5.57 \pm 1.29)$ \\
Social support $(5.85 \pm 1.45)$ & Maturity $(6.36 \pm 0.77)$ & Emotion $(4.46 \pm 1.35)$ \\
\hline \multicolumn{1}{c}{ Normative } & \multicolumn{1}{c}{ Existence } & Promotion \\
\hline Obedience $(6.47 \pm 0.80)$ & Stability $(6.39 \pm 0.97)$ & Power $(4.32 \pm 1.43)$ \\
Tradition $(5.59 \pm 1.17)$ & Health $(6.37 \pm 1.04)$ & Prestige $(4.58 \pm 1.67)$ \\
Religiosity $(6.54 \pm 0.92)$ & Survival $(6.40 \pm 0.85)$ & Success $(6.12 \pm 0.97)$ \\
\hline
\end{tabular}

Source: Elaborated by the authors.

To analyze the fit of the model, the following multiple fit indices were considered to assess the covariation structure (Byrne, 2001): goodness of fit index (GFI), root of the mean square error of approximation (RMSEA), standardized root mean square residual (SRMR) and comparative fit index (CFI). The first three measures are of absolute adjustment, and the last measure is of incremental adjustment (Hair et al., 2009). In the present study, the values found were satisfactory and corroborated the values of other studies (Gouveia et al., 2010; Medeiros, 2011). They are as follows: $\mathrm{GFI}=0.87$, RMSEA $=0.07, \mathrm{SRMR}=0,07$ and $\mathrm{CFI}=0.82$, values considered acceptable for the model.

After confirming the adequacy of the scale, the characteristics of the values obtained were verified. According to Figure 4.2, the two values of social orientation type obtained the highest average, while personnel was the two with the lowest average. It should be remembered that, according to Gouveia (2013), the orientation type guides human actions and can be classified as social, people who are guided by social values or have an interpersonal focus (social goals), personal, those guided by personal values are egocentric or they have an intrapersonal focus (personal goals), and the central, or mixed, which appears between the social and the personal, cognitively representing the main axis of human needs. In addition, the motivation type has the function of giving expression to human needs, be they materialistic (pragmatic) or idealistic (humanitarian). 


\section{(Figure 4.2)}

AVERAGES, DEVIATIONS, AND CHARACTERISTICS OF FUNCTIONAL VALUES

\begin{tabular}{lcccc}
\hline & \multicolumn{2}{c}{ Descriptive } & \multicolumn{2}{c}{ Dimension } \\
\hline Functional value & $m$ & sd & Orientation type & Motivation type \\
\hline Existence & 6.39 & 0.72 & Central & Materialist \\
\hline Normative & 6.20 & 0.73 & Social & Materialist \\
\hline Interactive & 5.66 & 1.06 & Social & Idealist \\
\hline supra-personal & 5.39 & 0.90 & Central & Idealist \\
\hline Excitement & 5.39 & 0.87 & Personal & Idealist \\
\hline Promotion & 5.01 & 0.96 & Personal & Materialist \\
\hline
\end{tabular}

Source: Elaborated by the authors.

Thus, Figure 4.2 shows a prevalence of more social than personal behavior orientation. In addition, the materialistic motivator type has a higher mean $(m)$ associated with the social and the central, while personal orientation has a higher mean associated with idealistic orientation, corroborating with what was found by Van Dun and Wilderom (2016), in which high-performance teams have more altruistic values. Thus, the values with the highest mean, existence, and normative (above 6.00), can represent people who were socialized in restricted environments and who have adherence to conventional norms (Gouveia, 2013). Such characteristics corroborate the military environment where tactical groups undergo rigorous training and strict rules to operate in a risky environment.

The achievement value, with an average of 5.01, was considered the least important value for police officers in tactical groups, despite being a value generally appreciated by young adults in the productive phase or individuals educated in disciplinary and formal contexts (Gouveia, 2013). The power and prestige value markers were principally evaluated with low importance, while the success marker presented a high average. Such result may indicate that the policemen of tactical groups value success in their life and profession, but they do not give so much importance to personal recognition and may reflect values referring to the group spirit that rejects those who want to stand out among workmates, prioritizing group recognition over the individual. It is worth mentioning that the supra-personal value, despite being a central value of the human being, did not have great final 
importance, mainly due to the beauty valuation marker that presented the lowest average importance; such response may represent the context of the tactical groups, of valuing group over individual prominence.

\subsection{Influence of values on relationships}

Before assessing the relationship values, the distinction between the values of the two groups analyzed was verified. Analysis of the sociometric differences between the groups showed that the Rotam group is mostly composed of police officers with more than ten years of service, $66.35 \%$, while the Patamo group is composed mostly of police officers with less than ten years of service, $73.44 \%$. For this reason, it was necessary to assess the difference in values between groups before analyzing the whole. Values of $\mathrm{p}<0.05$ were considered significant. The Rotam and Patamo groups showed a significant difference for Interactive values, $m=5.82$ (95\% CI, 5.60-6.04) and $m=5.40$ (95\% CI, 5.18-5.61), respectively, and for supra-personal values, $m=5.51$ (95\% CI, 5.34-5.69) and $m=5.18$ (95\% CI, 4.98-5.38). Such data corroborate the functionalist theory, in which those who value the supra-personal are most often older and more mature people. The interactive value may be related to the fact that the Rotam group maintains groupings with members of the same police vehicle, while the Patamo group has a policy of rotation of members so that everyone can work with everyone else.

Trust relationships were measured according to degree centrality and beta centrality of instrumental and expressive relationships. The networks were divided into four groups for each centrality, namely: "high centrality", "medium-high centrality", "medium-low centrality" and "low centrality". When checking the ANOVA of the functionalist values with the four groups of centralities, significance $(p<0.05)$ was obtained in the difference of the supra-personal value in the instrumental network, with actors grouped by beta centrality; and significant difference $(p<0.05)$ was found in the normative value in the expressive network, with actors grouped by beta centrality.

In Figure 4.1.1, only the difference between the groups "high beta centrality", $m=4.90$ (95\% CI, 4.49-5.31), and "medium-high centrality beta", $m=5.68$ (95\% CI, 5.43-5.94) were significant $(\mathrm{p}<0.01)$, responsible for the significance of the ANOVA of the supra-personal value with instrumental groups of beta centrality. In the normative value, only the difference between the group "medium-high centrality beta", $m=5.74$ (95\% CI, 5.21-6.26), and "low beta centrality", $m=6.28$ (95\% CI, 6.14-6.42) was significant $(\mathrm{p}<0.05)$, 
responsible for the significance of ANOVA in the normative value with the expressive groups of beta centrality. In the other groups of instrumental and expressive centralities, there was no significant difference between the functional values in the variance test.

\section{(Figure 4.1.1)}

\section{SUPRA-PERSONAL VALUES IN THE INSTRUMENTAL NETWORK AND NORMATIVE VALUES IN THE EXPRESSIVE NETWORK}

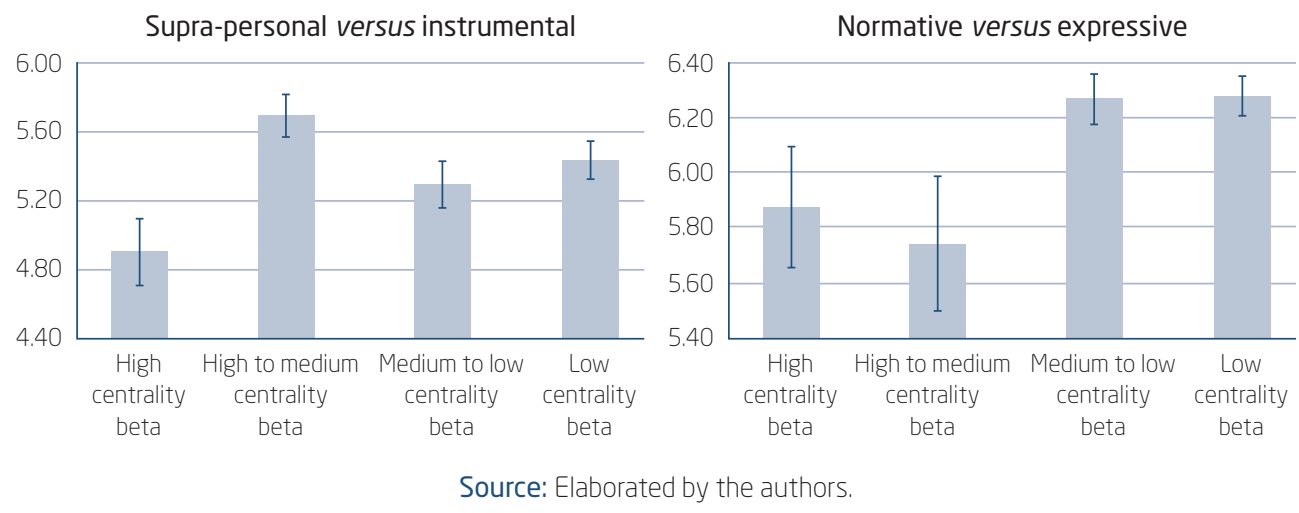

In the result found in the variances of the centrality groups, it was possible to verify some important points. First, it was only possible to find significance in groups through the beta centrality, in which not only the number of indications but the characteristics of those who trust were considered. In the instrumental network, it is observed that the supra-personal value has its significant difference between the two groups with the highest beta centrality and that its biggest drop is found in the most centralized group. Thus, the difference may indicate that the top group in group professional reputation is more focused on pragmatism and does not value abstract ideas as much (Gouveia, 2013).

In the expressive network, or in friendships, those with lower beta centrality, or those who presented a smaller number of affective ties, are also those who most value social norms such as the preservation of culture and conventional norms (Gouveia, 2013). Thus, people who place foremost importance on obedience and standards are less considered as far as affective trust is concerned.

To verify the linear relationships between functionalist personal values and the centralities in the relationships, a multiple regression was performed in which the six functional values were inserted as independent variables 
along with degree and beta centralities of each of the three networks totaling in multiple six regressions analyses.

The regression tests showed significance $(\mathrm{p}<0.05)$ only for the instrumental networks of degree centrality concerning the supra-personal and achievement values and for the expressive networks of beta centrality with reference to normative and achievement values. All other combinations of variables resulted in a non-significant model for $\mathrm{p}<0.05$. Thus, according to Figure 4.1.2, the $B$ and beta values and the influence of the supra-personal and achievement values on the degree centrality of the instrumental network with an $\mathrm{R}^{2}$ of 0.04 were obtained.

(Figure 4.1.2)

REGRESSION VALUES VERSUS DEGREE CENTRALITY OF THE INSTRUMENTAL NETWORK

\begin{tabular}{lcccc}
\hline & \multicolumn{2}{l}{ Nonstandard coefficients } & Standard coefficients & \\
\hline & B & Error & Beta & Sig. \\
\hline (Constant) & 0.063 & 0.027 & & 0.022 \\
\hline Supra-personal & -0.011 & 0.005 & -0.181 & 0.028 \\
\hline Promotion & 0.009 & 0.004 & 0.171 & 0.038 \\
\hline
\end{tabular}

Source: Elaborated by the authors.

The regression data in Figure 4.1.2 show the positive relationship between the Achievement value and the negative supra-personal value in the degree centrality of the instrumental network. Although the analysis of the groups was only significant for the beta centrality when relating the supra-personal value and the instrumental network, the regression reinforced the relationship, considering the degree of centrality in the negative relationship between them. The achievement value comes with a positive relationship with the professional reputation network.

In the analysis of the expressive network, beta centrality as a dependent variable obtained a significant model $(\mathrm{p}<0.05)$ for the normative and achievement values. According to Figure 4.1.3, the normative value has a negative relationship with the beta centrality in the expressive network; and the promotion value has a positive relationship and an $\mathrm{R}^{2}$ of 0.05 , thus, reaffirming the negative relation presented in the previous group analysis for the Normative value and expressive network and repeating the previous positive relation of the Promotion value. 


\section{(Figure 4.1.3)}

REGRESSION VALUES VERSUS BETA CENTRALITY
OF THE EXPRESSIVE NETWORK

\begin{tabular}{|c|c|c|c|c|}
\hline & \multicolumn{2}{|c|}{ Nonstandard coefficients } & \multicolumn{2}{|c|}{ Standard coefficients } \\
\hline & B & Error & Beta & Sig. \\
\hline (Constant) & 7.926 & 5.537 & & 0.154 \\
\hline Normative & -2.047 & 0.880 & -0.183 & 0.021 \\
\hline Achievement & 1.524 & 0.668 & 0.180 & 0.024 \\
\hline
\end{tabular}

Source: Elaborated by the authors.

From these analyses, it appears that, although the result found in the regression represents similar conclusions in the variables of negative influence on the networks, the information contained in the two analyses showed a greater value of details in understanding the relationships. In the analysis of variance, the beta centrality has a better representation of the results for the analysis of groups, since the weight of its composition, considering the types of bonds that the depositor of the trust has, makes evident the difference between having been cited by a person who mentioned several members and a person who named few or only one. Thus, the fact of making a distinction with weight for each type of relationship may better represent variance analyses. As a result, the groups with the highest instrumental beta centrality, which probably differed on the characteristics of this centrality, showed more pragmatic and less abstract values than the other members of medium-high centrality. In the expressive network, the two groups with less beta centrality, that is, with less effective trust relationships, are also the ones that most value conventional norms and obedience.

In the regression analysis, the values had a significant relationship with the instrumental network of degree and with the expressive network of beta, reinforcing the verification of the beta centrality for friendly relations and a better adaptation of the degree centrality to the professional reputation network. As a result, the negative relationship of the supra-personal value with the instrumental network and the Normative value with the expressive network denote that professional reputation relationships are directly linked to the valorization of pragmatism to the detriment of idealism, that is, to value the execution of the task more than the understanding of it. Such a result is understandable since the activity of police tactical groups falls into working groups whose occupation is to perform a task in which their result is 
measured in a predominantly pragmatic way. Friendship relations, on the other hand, were shown to be open to changes and less appreciation of the norm. Such findings corroborate those obtained by Riviera et al. (2014) regarding the importance of openness to change to solve ill-structured problems since actors with these characteristics have greater emotional ties in the group, but the relationship with performance after the restructuring of problems should be negative according to our study, thus, corroborating the conclusion that structuring the problem can also be considered a performance improvement.

It should be noted that, despite the significant results for the regressions, their effect on relationships had a low explanatory power $\left(\mathrm{R}^{2}\right)$. This result may indicate that, between the relationship of personal values and relationships, there may be an intermediate variable mediating or moderating this relationship, requiring further research to elucidate the data found. In addition, it should be considered that personal values are more abstract variables while relationships are more concrete and behavior-related variables.

\section{CONCLUSION}

Personal values can be considered individual characteristics, representing little alteration, which influences human behavior from outside the work environment, constantly in contact with the values of other members in the process of carrying out a task. Trust, an extremely important construct in group processes, has recently been better understood in organizations when analyzed separately in professional and personal relationships. Thus, the present study demonstrated the relationship of personal values in the team's trust structure, both professional and personal, and that there are values of professionals that can contribute to members with better or worse professional reputations. Workers with high achievement values tend to be more central in their personal and professional relationships, which consequently impacts on improving their group performance. On the other hand, workers with more ideological and less pragmatic values can negatively influence professional reputation, while valuing conventional norms and traditions negatively influences friendly relationships.

The results showed the importance of a team member with predominant execution characteristics and that those who are under pressure to save lives are open to change (or little normative) to improve intra-group relational conflicts. According to previous research, however, groups with these work characteristics can have a better intra-group professional reputation 
when they value pragmatism and achievement, that is, people who value performing the task and being successful are those who have a better reputation in the work environment, hence positively influencing their performance. Managerially, team leaders who work under pressure to save lives, like that of police tactical groups, can obtain better quantitative results by selecting members with more pragmatic values and who value achieving organizational goals. Members of more ideological values are likely to have better results in group tasks that require more abstraction, such as the creative and/or innovation sector.

Finally, the study was limited to conducting a cross-sectional analysis within the same police and social organizational culture. Analysis of other teams with similar characteristics of tasks with quantitative measurements, such as medical surgery teams and others that work under high alertness and who are at risk of saving or losing lives, is thereby suggested to consolidate results. Similar studies in different regions and cultures are also deemed important. The low explanatory values of regression suggest a future research agenda with intermediate variables, such as behavior between values and confidence. Qualitative research is suggested so that those investigated can externalize the construction of these values and how they affect the group's relationships. A longitudinal study is also necessary, since the constant relationships of trust with the exchange of experiences and sharing of values may, over time, have influenced the alteration of the personal values of the members of the group or also to verify whether personal values can be a selection factor for new members of specialized groups.

\section{VALORES PESSOAIS E RELACIONAMENTO INTRAGRUPO: O CASO DOS GRUPOS TÁTICOS POLICIAIS DE BRASÍLIA}

\section{RESUMO}

Objetivo: Este estudo tem como objetivo descrever como os valores pessoais dos membros de grupos de trabalho especializado impactam seus relacionamentos intragrupo baseados na confiança profissional e pessoal. Originalidade/valor: Três pontos norteiam as contribuições do presente estudo: 1. a consolidação de que a análise da confiança em grupos de trabalho tem resultados distintos nas relações instrumental (confiança profissional ou de reputação) e experimental (confiança pessoal ou de amizade) quando se verifica a diferença na predominância de valores 
pessoais para cada tipo de relacionamento; 2 . a utilização da teoria funcionalista dos valores humanos e de técnicas da análise de redes sociais (ARS) em conjunto com técnicas clássicas quantitativas, como a ANOVA e a regressão múltipla; 3 . em termos gerenciais, a verificação dos valores pessoais que favorecem a organização e o modo como se estruturam as relações de confiança no grupo.

Design/metodologia/abordagem: O presente estudo caracteriza-se como uma pesquisa de campo descritiva com abordagem quantitativa. Foi aplicada uma survey com 171 participantes de dois grupos táticos da polícia de Brasília, utilizando o questionário QVB de valores funcionalistas e um questionário com oito perguntas sobre os relacionamentos instrumental e expressivo. Utilizaram-se a análise fatorial confirmatória para evidenciar a validade do instrumento e a ARS para os relacionamentos de confiança. No caso das relações entre valores e relacionamentos, adotaram-se a ANOVA e a regressão múltipla.

Resultados: Os grupos táticos apresentaram características de valores pessoais mais pragmáticos e com menos valorização de individualismo, denotando características de valorização da execução e do coletivismo intragrupo. Os valores normativo e suprapessoal foram negativamente relacionados, respectivamente, às relações de amizade e profissionais, enquanto o valor realização foi positivamente relacionado às duas relações de confiança.

\section{PALAVRAS-CHAVE}

Valores pessoais. Confiança. Redes sociais. Amizade. Reputação profissional.

\section{REFERENCES}

Bernstein, M. (2007). Friends without favoritism. Journal of Value Inquiry, 41 (1), 59-76. doi:10.1007/s10790-007-9061-0

Bonacich, P. (1987). Power and centrality: A family of measures. American Journal of Sociology, 92 (5), 1170-1182. Retrieved fromhttps://www.jstor. org $/$ stable $/ 2780000$ ? seq $=1$ 
Borgatti, S. P., Everett, M. G., \& Johnson, J. C. (2018). Analyzing social networks. In J. Seaman (Ed.), Analyzing Social Networks (2nd ed., pp. 189-210). New York: Sage.

Braithwaite, V. A., \& Law, H. G. (1985). Structure of human values: Testing the adequacy of the Rokeach value survey. Journal of Personality and Social Psychology, 49(1), 250-263. doi:10.1037/0022-3514.49.1.250

Braithwaite, V. A., \& Scott, W. A. (1991). Values. In J. P. Robinson, P. R. Shaver, \& L. S. Wrightsman (Eds.), Measures of personality and social psychological attitudes (pp. 661-749). Harcourt Brace Jovanovich. doi:10.1016/ B978-0-12-590241-0.50016-2

Burt, R. S. (1992). Structural holes: The social structure of competition. Cambridge, MA: Harvard University Press. Retrieved fromhttp://search.epnet.com/ login.aspx? direct $=$ true $\& \mathrm{db}=\mathrm{ecn} \& \mathrm{an}=0405891$

Byrne, B. M. (2001). Structural equation modeling with AMOS: Basic concepts, applications, and programming. Mahwah, NJ: Lawrence Erbaum.

Castillo, I., Adell, F. L., \& Alvarez, O. (2018). Relationships between personal values and leadership behaviors in basketball coaches. Frontiers in Psychology, 12(9), 1-14. doi:10.3389/fpsyg.2018.01661

Crawford, E. R., \& Lepine, J. A. (2013). A configural theory of team processes: Accounting for the structure of taskwork and teamwork. Academy of Management Review, 38(1), 32-48. doi:10.5465/amr.2011.0206

De Jong, B. A., Dirks, K. T., \& Gillespie, N. (2016). Trust and team performance: A meta-analysis of main effects, moderators, and covariates. Journal of Applied Psychology, 101 (8), 1134-1150. doi:10.1037/apl0000110

Gouveia, V. V. (2003). A natureza motivacional dos valores humanos: Evidências acerca de uma nova tipologia. Estudos de Psicologia, 8(3), 431-443. doi:10.1590/S1413-294X2003000300010

Gouveia, V. V. (2013). Teoria funcionalista dos valores humanos. São Paulo: Casa do Psicólogo.

Gouveia, V. V., Milfont, T., Fischer, R., \& Coelho, J. (2009). Teoria funcionalista dos valores humanos: Aplicações para organizações. Revista de Administração Mackenzie, 10(3), 34-59. doi:10.1590/S1678-69712009000 300004

Gouveia, V. V., Milfont, T. L., \& Guerra, V. M. (2014a). Functional theory of human values: Testing its content and structure hypotheses. Personality and Individual Differences, 60, 41-47. doi:10.1016/j.paid.2013.12.012 
Gouveia, V. V., Milfont, T. L., \& Guerra, V. M. (2014b). The functional theory of human values: From intentional overlook to first acknowledgment - A reply to Schwartz (2014). Personality and Individual Differences, 68, 250-253. doi:10.1016/j.paid.2014.03.025

Gouveia, V. V., Santos, W. S., Milfont, T. L., Fischer, R., Clemente, M., \& Espinosa, P. (2010). Teoría funcionalista de los valores humanos en españa: Comprobación de las hipótesis de contenido y estructura. Interamerican Journal of Psychology, 44 (2), 213-224.

Hair, J. F., Black, W. C., Babin, B. J., Anderson, R. E., \& Tatham, R. L. (2009). Multivariate data analysis. Harlow, UK: Edinburgh Gate.

Henttonen, K., Janhonen, M., \& Johanson, J. (2013). Internal social networks in work teams: Structure, knowledge sharing and performance. International Journal of Manpower, 34(6), 616-634. doi:10.1108/IJM-062013-0148

Hofstede, G. H. (1980). Culture's consequences: International differences in workrelated values. New York: Sage.

Homer, P. M., \& Kahle, L. R. (1988). A structural equation test of the valueattitude-behavior hierarchy. Journal of Personality and Social Psychology, 54(4), 638-646. doi:10.1037/0022-3514.54.4.638

Kluckhohn, C. (1951). Values and value-orientation in the theory of action: An exploration in definition and classification. Toward a General Theory of Action, 388-433. doi:10.4159/harvard.9780674863507.c8

Korsgaard, M. A., Brower, H. H., \& Lester, S. W. (2015). It isn't always mutual: A critical review of dyadic trust. Journal of Management, 41 (1), 47-70. doi:10.1177/0149206314547521

Levy, S. (1990). Values and deeds. Applied Psychology, 39(4), 379-400. doi:10. 1111/j.1464-0597.1990.tb01062.x

Lewin, K. (1947). Frontiers in group dynamics: Concept, method and reality in social science; social equilibria and social change. Human Relations, 1(1), 5-41. doi:10.1177/001872674700100103

Lima, J. L. de A., Neto, \& Pereira, H. B. de B. (2017). A rede social de ajuda-mútua de Narcóticos Anônimos: A relevância do prestígio, da centralidade de intermediação entre os membros. Revista Hispana para el Análisis de Redes Sociales, 28(1), 91-103.

Marconi, M., \& Lakatos, E. (2003). Fundamentos de metodologia científica. São Paulo: Atlas. 
Marteleto, R. M. (2001). Análise de redes sociais: Aplicação nos estudos de transferência da informação. Ciência da Informação, 30(1), 71-81. doi:10.15 90/S0100-19652001000100009

Martins, D. M., Faria, A. C. de, Prearo, L. C., \& Arruda, A. G. S. (2017). The level of influence of trust, commitment, cooperation, and power in the interorganizational relationships of Brazilian credit cooperatives. Revista de Administração, 52(1), 47-58. doi:10.1016/j.rausp.2016.09.003

Maslach, C., \& Leiter, M. P. (2008). Early predictors of job burnout and engagement. Journal of Applied Psychology, 93(3), 498-512. doi:10.1037/ 0021-9010.93.3.498

Maslow, A. H. (1954). Motivation and personality. New York: Harper \& Brothers.

Mayfield, C. O., Tombaugh, J. R., \& Lee, M. (2016). Psychological collectivism and team effectiveness: Moderating effects of trust and psychological safety. Journal of Organizational Culture, Communications and Conflict, 20(1), 78-95.

McAllister, D. J. (1995). Affect and cognition-based trust as foundations for interpersonal cooperation in organizations. Academy of Management Journal, 38(1), 24-59. doi:10.2307/256727

Medeiros, E. D. de (2011). Teoria funcionalista dos valores humanos: Testando sua adequação intra e interculturalmente (Tese de doutorado, Universidade Federal da Paraíba, João Pessoa, PB, Brasil). Retrieved fromhttps://repositorio. ufpb.br/jspui/handle/tede/6877?locale $=$ pt_BR

Medeiros, E. D. de, Gouveia, V., Gusmao, E., Milfont, T., Fonseca, P., \& De Aquino, T. (2012). Teoria funcionalista dos valores humanos: Evidências de sua adequação no contexto paraibano. Revista de Administração Mackenzie, 13(3), 18-44. doi:10.1590/S1678-69712012000300003

Medeiros, E. D. de, Pimentel, C. E., Monteiro, R. P., Gouveia, V. V., \& Medeiros, P. C. B. de (2015). Valores, atitudes e uso de bebidas alcoólicas: Proposta de um modelo hierárquico. Psicologia: Ciência e Profissão, 35(3), 841-854. doi:10.1590/1982-3703001532013

Milfont, T. L., Duckitt, J., \& Wagner, C. (2010). The higher order structure of environmental attitudes: A cross-cultural examination. Interamerican Journal of Psychology, 44(2), 263-273.

Nahapiet, J., \& Ghoshal, S. (1998). Social capital, intellectual capital, and the organizational advantage. The Academy of Management Review, 23(2), 242-266. doi:10.5465/amr.1998.533225

Reed, M. I. (2001). Organization, trust and control: A realist analysis. Organization Studies, 22(2), 201-228. doi:10.1177/0170840601222002 
Riviera, J. R., Domenico, S. M. R., \& Sauaia, A. C. A. (2014). Influence of individual values dissimilarity in the outcome of top management teams: A study in a management lab. Review of Business Management, 16(50), 60-74.

Rokeach, M. (1973). The nature of human values. New York: Free Press.

Rousseau, D. M., Sitkin, S. B., Burt, R. S., \& Camerer, C. (1998). Not so different after all: A cross-discipline view of trust. Academy of Management Review, 23(3), 393-404. doi:10.5465/amr.1998.926617

Ryan, S. (2004). Initial trust formation in an online social action network. Contesting Citizenship and Civil Society in a Divided World. Ryerson University and York University Toronto, Canada, 1-25.

Schwartz, S. (2006). A theory of cultural value orientations: Explication and applications. Comparative Sociology, 5(2-3), 137-182. doi:10.1163/15691 3306778667357

Schwartz, S. H. (1992). Universals in the content and structure of values: Theoretical advances and empirical tests in 20 countries. Advances in Experimental Social Psychology, 25(C), 1-65. doi:10.1016/s0065-2601(08)60281-6

Schwartz, S. H. (2012). An overview of the Schwartz theory of basic values. Online Readings in Psychology and Culture, 2(1), 1-20. doi:10.9707/23070919.1116

Schwartz, S. H. (2014). Functional theories of human values: Comment on Gouveia, Milfont, and Guerra (2014). Personality and Individual Differences, 68, 247-249. doi:10.1016/j.paid.2014.03.024

Schwartz, S. H., Cieciuch, J., Vecchione, M., Davidov, E., Fischer, R., Beierlein, C., Ramos, A., Verkasalo, M., Lönnqvist, J.-E., Demirutku, K., Dirilen-Gumus, O., \& Konty, M. (2012). Refining the theory of basic individual values. Journal of Personality and Social Psychology, 103(4), 663-688. doi:10.1037/a0029393

Sortheix, F. M., \& Lönnqvist, J.-E. (2015). Person-group value congruence and subjective well-being in students from Argentina, Bulgaria and Finland: The role of interpersonal relationships. Journal of Community \& Applied Social Psychology, 25(1), 34-48. doi:10.1002/casp.2193

Thomas, W., \& Znaniecki, F. (1919). The Polish peasant in Europe and America: Monograph of an immigrant group. The University of Chicago Press, 3, 18-22.

Thorelli, H. B. (1986). Network: Between markets and hierarchies. Strategic Management Journal, 7(1), 37-51. doi:10.1002/smj.4250070105 
Torres, C. V., Schwartz, S. H., \& Nascimento, T. G. (2016). A teoria de valores refinada: Associações com comportamento e evidências de validade discriminante e preditiva. PsicologiaUSP, 27(2), 341-356. doi:10.1590/0103656420150045

Van Dun, D. H., \& Wilderom, C. P. M. (2016). Lean-team effectiveness through leader values and members' informing. International Journal of Operations \& Production Management, 36(11), 1530-1550. doi:10.1108/ IJOPM-06-2015-0338

Vergueiro, W., \& Sugahara, C. R. (2010). Aspectos conceituais e metodológicos de redes sociais e sua influência no estudo de fluxos de informação. Revista Digital de Biblioteconomia e Ciência da Informação, 7(2), 102-117. doi:10.20396/rdbci.v7i2.1959

Wasserman, S., \& Faust, K. (1994). Social network analysis: Methods and applications. Cambridge: Cambridge University Press.

Whitener, E. M., Brodt, S. E., Korsgaard, M. A., \& Werner, J. M. (1998). Managers as initiators of trust: An exchange relationship framework for understanding managerial trustworthy behavior. The Academy of Management Review, 23(3), 513-530. doi:10.5465/amr.1998.926624

\section{AUTHOR NOTES}

Fagner O. Dias, master from the Graduate Program in Administration (PPGA), University of Brasília (UnB); Edgar Reyes Junior, Ph.D. from the Graduate Program in Administration (PPGA), University of Vale do Rio dos Sinos (Unisinos); Caroline C. B. Costa, master from the PPGA-UnB; Andréia E. S. Barros, master from the PPGA-UnB.

Fagner O. Dias is now a Ph.D. student at the PPGA-UnB; Edgar Reyes Junior is now postgraduate coordinator and assistant professor at the PPGA-UnB; Caroline C. B. Costa is now a Ph.D. at the PPGA-UnB; Andréia E. S. Barros is now a Ph.D. student at the PPGA-UnB.

Correspondence concerning this article should be addressed to Fagner O. Dias, Campus Universitário Darcy Ribeiro, Asa Norte, Brasília, Distrito Federal, Brasil, CEP 70910-900.

E-mail: fagner.pmdf@gmail.com

$\begin{array}{ll}\text { EDITORIAL BOARD } & \text { EDITORIAL PRODUCTION } \\ \begin{array}{l}\text { Editor-in-chief } \\ \text { Gilberto Perez }\end{array} & \text { Publishing coordination } \\ & \text { Jéssica Dametta } \\ \text { Associate editor } & \text { Language editor } \\ \text { Renata Silva de Carvalho Chinelato } & \text { Daniel de Almeida Leão } \\ \text { Technical support } & \text { Layout designer } \\ \text { Vitória Batista Santos Silva } & \text { Emap } \\ & \text { Graphic designer } \\ & \text { Libro }\end{array}$

